\title{
Educating Children's Rights and Responsibilities for Elementary School Students of Tay-Nung Ethnic Groups in the Northern Mountainous Regions - Vietnam
}

\author{
Nguyen Thi Ngoc ${ }^{*}$, Nguyen Thi Thanh Huyen \\ Faculty of Psychology and Education, Thai Nguyen University, Vietnam
}

Received July 23, 2020; Revised September 4, 2020; Accepted September 23, 2020

\section{Cite This Paper in the following Citation Styles}

(a): [1] Nguyen Thi Ngoc, Nguyen Thi Thanh Huyen, "Educating Children's Rights and Responsibilities for Elementary School Students of Tay-Nung Ethnic Groups in the Northern Mountainous Regions - Vietnam," Universal Journal of Educational Research, Vol. 8, No. 11, pp. 5425 - 5432, 2020. DOI: 10.13189/ujer.2020.081145.

(b): Nguyen Thi Ngoc, Nguyen Thi Thanh Huyen (2020). Educating Children's Rights and Responsibilities for Elementary School Students of Tay-Nung Ethnic Groups in the Northern Mountainous Regions - Vietnam. Universal Journal of Educational Research, 8(11), 5425 - 5432. DOI: 10.13189/ujer.2020.081145.

Copyright $\odot 2020$ by authors, all rights reserved. Authors agree that this article remains permanently open access under the terms of the Creative Commons Attribution License 4.0 International License

\begin{abstract}
Educating children's rights and responsibilities for Tay and Nung elementary school students is an important educational content contributing to the implementation of comprehensive educational goals for ethnic minority pupils of primary schools who are living in the mountainous areas of Northern Vietnam. The rights and duties of students are mainly carried out in life and are greatly influenced by cultural characteristics of the nation such as customs, ways of life, communication, festivals, beliefs, spirituality, etc. The problem is to clarify the theoretical basis for using local knowledge in educating students' rights and responsibilities, analyzing the reality of exploiting local knowledge in educating Tay and Nung elementary school students. Since then some measures are proposed to educate children's rights and responsibilities through the use of local knowledge in the Northern Upland region. In this paper, the author has used a paper-based survey method and direct interviews with students and teachers in 6 mountainous provinces in Northern Vietnam. The survey was conducted by the support of 618 Tay-Nung ethnic minority students and 245 teachers and administrators. Through the results achieved in this study, we need to integrate the education of children in this mountainous area by incorporating real life. The habits and culture of mountainous children need to be emphasized in education because this combination makes sense for educating students' rights and obligations. Besides, we can preserve the cultural identity of the Tay and Nung ethnic
\end{abstract}

groups. This is of great significance in designing a complete educational program that aims to educate the children.

Keywords Local Knowledge, Education, Rights and Responsibilities, Elementary School Student, Tay and Nung Ethnic Groups

\section{Introduction}

In the context of social life today, the issue of child rights violations is complicated in many countries around the world. Therefore, it is imperative to increase the education of children's rights and responsibilities for elementary school children. Elementary students in each ethnic minority community living in different localities enjoy children's rights and perform their duties with unique characteristics. These rights and duties must conform to the culture, customs, practices and lifestyles of the local ethnic community. Tay and Nung elementary school students in the northern mountainous areas of Vietnam enjoy a rich spiritual life with cultural values imbued with national characteristics. That is the local knowledge contained in customs, practices, ways of life, communication, festivals, beliefs, spirituality, etc. If we know how to exploit the local knowledge to apply to the teaching process education on 
children's rights and duties for Tay and Nung elementary school students, this will contribute to enriching educational content, linking educational content with real life of students, and regional cultural characteristics [1].

On the basis of theoretical studies on the education of children's rights and responsibilities and the localization of local knowledge of the Tay - Nung ethnic community in the mountainous areas of Northern Vietnam in combination with surveying the educational situation, the school has used local knowledge to educate children's rights and responsibilities, the author aims to develop measures to use local knowledge in the education of children's rights and responsibilities to the highest efficiency [2].

\section{Content of Research}

\subsection{The Basics of Local Knowledge}

Local knowledge (folk knowledge) from the approach point of view in this research topic is the whole understanding of the community about nature, society and people themselves, accumulated in the field of history through the experience of the community itself. Such knowledge is passed on to successive generations through memory, word of mouth, and social practice. It helps people to have appropriate behaviors with the natural environment, regulate social relationships, necessary knowledge in production, nourishment and treatment. Local knowledge of each community is compatible with the natural environment, social situations and certain cultural development levels [3].

\subsection{Characteristics of Local Knowledge}

There are a number of criteria that identify cultural characteristics as local knowledge used in primary school education. The Tay and Nung communities are two different ethnic groups, but they share the same language and have the same historical origin divided from the Tay-Thai language group, with ties to the Chinese and Thai people in Northwest Vietnam. The ethnic identity of the Tay and Nung people, especially the indigenous people in the mountainous areas of Northern Vietnam, is very diverse and plentiful. However, not all cultural features are knowledge that can be used in student education. Choosing the local knowledge to use in education is a job that requires educators to research, collect and compile [4].

When studying the indigenous culture of the Tay Nung people in the northern mountainous region of Vietnam for use in the process of educating primary school pupils, the author summarizes the criteria for identifying a defined cultural feature. Local knowledge is as follows:

Criterion 1: Cultural characteristics need to be highly reliable, not superstitious, unscientific.

Based on the assessment based on scientific views on phenomena to evaluate the reliability of customs, practices, rituals or folk experiences of the Tay - Nung community serving for educational purpose, resolutely eliminate the signs of superstition and non-scientific in the community.

Criterion 2: Cultural characteristics with humane content, meaningful to educate students.

The purpose of exploiting local knowledge to use as a means of conveying educational content so that the selected knowledge should have educational significance and promote the characteristics of local knowledge to promote humanity. poignant literature.

Criterion 3: Cultural characteristics are popular and widely disseminated in the local community.

Local knowledge is defined as familiar knowledge in life and activities of the majority of people in the community. These are understandable and easy-to-remember knowledge that is suitable for the majority of people, including those who are not yet highly educated [5]. Due to the regional characteristics, there are cultural features taking place in one locality but not typical in other localities, teachers need to base on each specific area to choose to use local knowledge with different forms. They should use different ways of existence to organize teaching and educating students.

Criterion 4: Cultural characteristics are recognized by indigenous people, voluntarily implemented, ensuring their durability.

The fundamental value of local knowledge is the recognition in community life with lasting vitality through many generations and stages [3]. Many customs and practices are not coercive like state laws but are voluntarily obeyed by people. Educators when using the cultural characteristics of the community to educate students need the consent and recognition from indigenous people to be able to successfully carry out that educational process.

Criterion 5: Knowledge is suitable for the awareness level of Tay and Nung elementary school students

Local knowledge of the Tay and Nung communities is used in the process of educating children's rights and responsibilities, so it is necessary to ensure the conformity with the awareness level of Tay and Nung elementary school students. Teachers need to take into account the psychological characteristics, conceptions, habits of students to design teaching content and organize education activities using appropriate local knowledge [6].

In the process of studying cultural documents of the Tay and Nung people combined with fieldwork, we identify some local knowledge content that exists in the following cultural categories (table 1). 
Table 1. Types of local culture

\begin{tabular}{|c|c|c|}
\hline No & The form of existance & Type of culture \\
\hline 1 & Customs and practices & $\begin{array}{ll}\text { - } & \text { Vocational transmission } \\
\text { - } & \text { Birthday celebration for the elderly } \\
\text { - } & \text { Pen and paper handover ceremony } \\
\text { - } & \text { Proverb "sum" } \\
\text { - } & \text { The custom of sleeping } \\
\text { - } & \text { Proclaimed to them } \\
\text { - } & \text { Adoption process } \\
\text { - } & \text { New rice eating customs } \\
\text { - } & \text { Use the language and traditional costumes }\end{array}$ \\
\hline 2 & Folk poetry, proverbs, idioms & $\begin{array}{ll}\text { - } & \text { Proverbs about affection between parents and children } \\
\text { - } & \text { Love proverbs siblings } \\
\text { - } & \text { Proverbs about social behavior } \\
\end{array}$ \\
\hline 3 & Folk tales & $\begin{array}{ll}- & \text { Stories about friendship } \\
\text { - } & \text { Stories about affection of parents - children }\end{array}$ \\
\hline 4 & Life experience & $\begin{array}{ll}- & \text { Predict the weather } \\
\text { - } & \text { Folk healing } \\
\text { - } & \text { Labor, production }\end{array}$ \\
\hline 5 & Belief, spirituality & $\begin{array}{ll}- & \text { Ancestor worship } \\
\text { - } & \text { Legend of the sacred forest } \\
\end{array}$ \\
\hline 6 & Art & $\begin{array}{ll}- & \text { Lullaby } \\
- & \text { Singing “sli”, gliding song } \\
- & \text { Lion dance, martial dance } \\
\end{array}$ \\
\hline 7 & Convention & $\begin{array}{ll}- & \text { Anti-theft convention } \\
\text { - The convention of making a contribution to and contribution of a working } \\
\text { family }\end{array}$ \\
\hline 8 & Festivals and games & $\begin{array}{ll} & \text { "lồng tồng" festival } \\
\text { • } & \text { "Tung con" games }\end{array}$ \\
\hline
\end{tabular}

The outstanding cultural characteristics of the Tay Nung ethnic community is based on the above system, which contains the knowledge content of productive, behavioral, living activities, etc. Children's responsibilities for Tay - Nung elementary school students can be generalized into the following types of knowledge:

- Knowledge of family behavior, parenting and education

- Knowledge of social relations between people

- Knowledge of human relationships with the natural environment

- Traditional cultural knowledge in the emotional life

- Knowledge of productive labor activities

- Cultural knowledge in the spiritual and spiritual life of people

- Cultural knowledge in community and village management

2.2.1. Ways of using local knowledge in educating children's rights and responsibilities for Tay and Nung elementary school students

- $\quad$ Integrating the use of integrated local knowledge in the content of teaching subjects with advantages.

- $\quad$ Organize an examination to learn about the content of local knowledge that educates children's rights and responsibilities for students [7].

- $\quad$ Organizing for students to collect local knowledge content that educates children's rights and responsibilities.
- Organizing theatrical activities such as plays, singing competitions, role play to handle situations to learn about the rights and obligations of children using materials from the specific cultural knowledge of the Tay and Nung people. local.

- $\quad$ Organizing for students to participate in festivals and traditional folk games of the Tay and Nung communities.

\subsection{Practical Bases of Using Local Knowledge in Educating Children's Rights and Responsibilities for Tay and Nung Elementary School Students in the Northern Mountainous Area}

2.3.1. Practical experiences on the education of children's rights and responsibilities in the world and in Vietnam

Children's rights education always receives the attention of many countries and international organizations around the world, especially the United Nations Children's Fund. In response to the spirit of the International Convention on the Rights of the Child, child relief organizations have implemented many action plans and programs for the benefit of children. Most child-related actions of countries around the world follow two major trends [8].

The first is directed at different types of children and addresses children's entitlements. The US, UK and some developed countries are among the countries that 
represent this trend. Studies on children are carried out in the form of social policies such as determining the situation of homeless children, children living in slums in the heart of big cities, sick children, HIV infection, etc. and supportive policies to meet the basic rights of this group of children

The second trend addresses the different areas of access to child rights such as child labor protection, child sexual abuse, etc. The way to ensure children's rights in this trend is based on research results to support children through the activities of international organizations and child relief organizations. This trend occurred mainly in some African countries [9].

In some Asian countries such as India, Singapore, Indonesia, etc. the issue of children's rights is addressed by taking care of every aspect of the child, so education to improve children's rights is realized [7]. Currently, in many ways such as through school education or dissemination through the mass media, social networks, etc. Singapore is one of the countries in the region to effectively implement the education of children's rights. and ensure the rights of children in life [10].

Although the issue of children's rights education is widely carried out in countries around the world with many different trends, linking this educational process with exploiting regional cultural characteristics as a way Child educational facilities are hardly mentioned.

\subsubsection{Survey purpose}

We are assessing the situation of organizing child rights and educational activities for the Tay and Nung ethnic minority pupils in the region in such aspects as teachers' perceptions of rights education and children's duties, the role of local knowledge in the above-mentioned educational process; content education rights and obligations; methods and methods of organizing educational activities; influencing factors and causes of the situation.

\subsubsection{Respondents}

The project conducts a field survey in 6 provinces in the Northern mountainous region of Vietnam with 245 managers and teachers; 618 primary pupils are Tay and Nung ethnic minority, of which Thai Nguyen province has 110 students and 35 teachers, Bac Kan has 101 students and 30 teachers, Ha Giang has 98 students and 42 teachers, Tuyen Quang has 113 students and 42 teachers, Cao Bang has 100 students and 60 teachers, Lang Sơn 96 students and 36 teachers.

\subsubsection{Survey scope}

The paper focuses on studying at a number of primary schools located in the mountainous districts of 6 northern mountainous provinces with the majority of Tay and Nung ethnic minority pupils studying and living.

\subsubsection{Survey method}

The method is designed into two sets of questions: The questionnaire for teachers and educational managers to collect information on the current state of organizing rights and obligations education activities. Children's part for Tay and Nung students, the situation of using local knowledge in the process of organizing children's rights and children's rights education activities for Tay and Nung elementary students.

The questionnaire for Tay and Nung elementary students is used to understand their perceptions of their rights and duties and to collect initial information about the effectiveness of using local knowledge in education of rights and obligations for elementary students of Tay and Nung.

Interview method: Directly interview some teachers and students to collect information and explain some causes of the situation.

Methods of summarizing practical experiences: used in the study of academic results (ethics) and to learn about children's rights and responsibilities education activities organized in schools, level of participation of students (educational activities outside of class time).

\subsubsection{Method of processing survey results}

Using Ecxel and SPSS 16.0 software to analyze data obtained from the situation, interpret the parameters and represent diagrams illustrating the actual results.

\subsubsection{Survey results}

We conduct surveys on teachers and educational institution perceptions of issues such as the advantages of local knowledge; purpose of using local knowledge; content of rights and obligations to be educated; forms and methods of using local knowledge in education of Tay and Nung elementary school students. In general, teachers appreciated the advantages of local knowledge in educating rights and responsibilities for Tay and Nung elementary school students (71\%); The number of teachers who think that local knowledge has no advantage in educating students' rights and duties is only $12.2 \%$.

Teachers in the northern mountainous provinces believe that the greatest purpose of exploiting local knowledge to educate students is to "promote the role and educational significance of national identity". According to 189 (77.1\%) teachers, using local knowledge in the education of children's rights and responsibilities also contributes to preserving, promoting and enriching such knowledge. There are 179 (73.1\%) teachers who think that using local knowledge will concretize the rights and responsibilities of children, making them easy to understand, remember and apply.

Regarding the content of the rights and duties that are educated through the use of local knowledge: To evaluate this section, we convention the following scores: each teacher rights group indicates 1 point, maximum of 4 
points with 4 rights groups. Content of the obligation has 3 , each content of the obligation indicates 1 point, the maximum score is 3 points.

Teachers in Ha Giang province have the best awareness with an average of 2.05; The teacher in Bac Kan province had the lowest awareness with an average score of 1.13. The average score between the provinces is relatively large. The average perception of teachers surveyed in the provinces with children's rights was 1.64. Thus, the absolute point correlation can be seen that the teacher's awareness is below average. The majority of teachers are not fully aware of the content of rights groups with educational advantages through the use of local knowledge.

\subsection{Awareness of Teachers About the Content of Children's Responsibilities}

Teachers in Ha Giang province have the best awareness with an average of 2.05. The teacher in Bac Kan province had the lowest awareness with an average score of 1.13. The average score between the provinces is relatively large. The average perception of teachers surveyed in the provinces with children's rights was 1.64 . Thus, the absolute point correlation can be seen that the teacher's awareness is below average. The majority of teachers are not fully aware of the content of rights groups with educational advantages through the use of local knowledge.

\section{Awareness of teachers about the content of children's responsibilities}

The average of teachers' perceptions of the content of children's obligations to be educated using local knowledge is 1.76. Correlating with an absolute score of 3.0 , it can be seen that teachers in the provinces are quite aware of the content of the duty to be educated through the use of local knowledge. However, the average difference between provinces is quite large, with teachers in Cao Bang ranked first with an average score of 2.3, while teachers in Ha Giang province had the lowest average score of 1.36 , so the difference is approximately 1 point.

Awareness of teachers on forms and methods of using local knowledge in educating children's rights and responsibilities for Tay and Nung elementary school students. Teachers' awareness of the use of local knowledge in rights and responsibilities education for Tay - Nung elementary school students
In the questionnaire, we provide four types of concretization from the teaching activity and the dominant educational activity to using local knowledge and asking the teacher to choose. In order to facilitate the evaluation of cognitive results, we convention that each form of teacher indicates a convention of 1 point, so the maximum score is 4 . The survey shows that the total points of teacher awareness. In the survey area, there are 558 points and the average score is 2.28 . It can be seen that teachers are above the average level of awareness on forms of use. In which teachers in Ha Giang province have a fairly good awareness with an average score of 2.98, ranked No. 1. Ranked in the last position is a teacher in Tuyen Quang with an average score of 1.62 .

- Teachers' awareness of how to use local knowledge to educate children's rights and responsibilities [6].

We use the same convention as the formal section, with 8 methods giving a maximum score for this content of 8 points. The average of teachers' methodological average score is 4.17. Correlating with absolute scores, the awareness of primary teachers is above average. Teachers in Thai Nguyen province had the highest average GPA of 5.46; With an average score of 2.88, teachers in Cao Bang Province had the cognitive scores ranked at the last position in the summary table.

* Overall assessment of cognitive survey results: In general, primary teachers in the Northern mountainous provinces have an average awareness of the use of local knowledge in rights and duties education. Children's department for Tay and Nung elementary school students. The proportion of teachers who assess local knowledge has an advantage in the education of rights and responsibilities for students is relatively high. Most teachers assessed the purpose but did not know much about the content, form and method of using local knowledge in educating students' rights and responsibilities [9].

In view of the above reality, we conducted a practical survey using teachers' local knowledge in educating children's rights and responsibilities in terms of content, form and method of use for clarification.

Surveying the situation of using local knowledge in educating children's rights and responsibilities for Tay and Nung elementary school students

The first survey content we want to find out the percentage of teachers using local knowledge, the results shown in Table 2 below.

Table 2. Percentage of teachers using local knowledge in pedagogical and pediatric education for Tay - Nung elementary school students

\begin{tabular}{|c|c|c|c|c|c|c|c|c|}
\hline No & Opinion & Cao Bang & Bac Kan & Lang Son & Thai Nguyen & Tuyen Quang & Ha Giang & Total \\
\hline \multirow{2}{*}{1} & \multirow{2}{*}{ Yes } & 37 & 12 & 18 & 13 & 14 & 23 & 117 \\
& & $61,7 \%$ & $40 \%$ & $50 \%$ & $37,1 \%$ & $33,3 \%$ & $54,8 \%$ & $47,8 \%$ \\
\hline \multirow{2}{*}{2} & \multirow{2}{*}{ No } & 23 & 18 & 18 & 22 & 28 & 19 & 128 \\
& & $38,3 \%$ & $60 \%$ & $50 \%$ & $62,9 \%$ & $66,7 \%$ & $45,2 \%$ & $52,2 \%$ \\
\hline
\end{tabular}


Looking at the table above, we see that in the provinces in the region, teachers have exploited the local cultural knowledge to educate students' rights and responsibilities, but the ratio of the provinces have relatively large disparities. Teachers in Cao Bang province have the highest use rate with $61.7 \%$ and the lowest is teachers in Tuyen Quang province with 33.3\%, which is only about half of the province with the highest use rate.

The second content of the local knowledge content is used to educate the rights and responsibilities of Tay and Nung elementary school students. The results are shown in Table 2. Teachers have used local knowledge to educate the children's rights and responsibilities the most for students through teaching Ethics, which is also used by $7.7 \%$ of teachers very often; $21.4 \%$ use regularly; $52.1 \%$ of teachers use it occasionally; $18.8 \%$ of teachers have not used this method yet.

Forms of organizing extracurricular educational activities have $4.3 \%$ of teachers regularly use; $9.4 \%$ of teachers regularly use; $46.2 \%$ of teachers do not organize this form of education yet, the remaining $40.1 \%$ of teachers occasionally organize an education of rights and obligations for students to use educational facilities as cultural knowledge of the Tay and Nung ethnic groups in the locality.

By learning about the practice of using local knowledge to organize rights and responsibilities education activities for elementary students, we find that there are two forms of advantages organized by teachers rather than through teaching ethics and organizing extracurricular activities [10]. Therefore, we conduct a systematic study of methods of using local knowledge in the education of rights and responsibilities for students in the above two forms of education. The results of the methodological status survey are shown in tables 3 and 4 below.

In the system of methods which outlined the most used discussion method with 25/117 (39.5\%) teachers selected, this is a very dominant method to integrate local knowledge in education for students. Folk storytelling method ranked second with $36.5 \%$ of teachers used; practical and practical methods used by $33.3 \%$ of teachers, ranked third in the summary table.

The methods teachers use less in the process of using local knowledge to educate students when organizing out-of-class-hour educational activities is the method of organizing games (19\% of teachers choose) and practicing vi suitable with the rights and obligations of students (15.9\% of teachers choose).

Table 3. Methods of using local knowledge to educate rights and obligations of Tay - Nung elementary school students in out-of-class-hour educational activities

\begin{tabular}{|c|c|c|c|c|c|c|c|c|}
\hline No & Method & Cao Bang & Bac Kan & $\begin{array}{l}\text { Lang } \\
\text { So'n }\end{array}$ & $\begin{array}{c}\text { Thai } \\
\text { Nguyen }\end{array}$ & $\begin{array}{l}\text { Tuyen } \\
\text { Quang }\end{array}$ & $\begin{array}{c}\text { Ha } \\
\text { Giang } \\
\end{array}$ & Total \\
\hline 1 & Organize games & $\begin{array}{c}4 \\
21,1 \% \\
\end{array}$ & 0 & 0 & $\begin{array}{c}4 \\
80 \% \\
\end{array}$ & 0 & $\begin{array}{c}4 \\
25 \% \\
\end{array}$ & $\begin{array}{c}12 \\
19 \% \\
\end{array}$ \\
\hline 2 & Discussion & $\begin{array}{c}6 \\
31,6 \% \\
\end{array}$ & $\begin{array}{c}1 \\
14,3 \% \\
\end{array}$ & $\begin{array}{c}2 \\
33,3 \% \\
\end{array}$ & $\begin{array}{c}5 \\
100 \% \\
\end{array}$ & $\begin{array}{c}6 \\
60 \% \\
\end{array}$ & $\begin{array}{c}5 \\
31,2 \% \\
\end{array}$ & $\begin{array}{c}25 \\
39,7 \% \\
\end{array}$ \\
\hline 3 & $\begin{array}{c}\text { Train behaviors in accordance } \\
\text { with rights and duties }\end{array}$ & $\begin{array}{c}2 \\
10,5 \% \\
\end{array}$ & $\begin{array}{c}1 \\
14,3 \% \\
\end{array}$ & 0 & $\begin{array}{c}2 \\
40 \% \\
\end{array}$ & $\begin{array}{c}4 \\
40 \% \\
\end{array}$ & $\begin{array}{c}1 \\
6,2 \% \\
\end{array}$ & $\begin{array}{c}10 \\
15,9 \% \\
\end{array}$ \\
\hline 4 & Telling folkloreStory & $\begin{array}{c}5 \\
26,3 \% \\
\end{array}$ & $\begin{array}{c}1 \\
14,3 \% \\
\end{array}$ & $\begin{array}{c}2 \\
33,3 \% \\
\end{array}$ & $\begin{array}{c}2 \\
40 \% \\
\end{array}$ & $\begin{array}{c}4 \\
40 \% \\
\end{array}$ & $\begin{array}{c}9 \\
56,2 \% \\
\end{array}$ & $\begin{array}{c}23 \\
36,5 \% \\
\end{array}$ \\
\hline 5 & Practice & 0 & $\begin{array}{c}2 \\
28,6 \% \\
\end{array}$ & $\begin{array}{c}5 \\
83,35 \\
\end{array}$ & $\begin{array}{c}4 \\
80 \% \\
\end{array}$ & $\begin{array}{c}5 \\
50 \% \\
\end{array}$ & $\begin{array}{c}5 \\
31,2 \% \\
\end{array}$ & $\begin{array}{c}21 \\
33,3 \% \\
\end{array}$ \\
\hline 6 & Case study & $\begin{array}{c}7 \\
36,8 \% \\
\end{array}$ & $\begin{array}{c}2 \\
28,6 \%\end{array}$ & $\begin{array}{c}1 \\
16,7 \% \\
\end{array}$ & 0 & $\begin{array}{c}4 \\
40 \% \\
\end{array}$ & $\begin{array}{c}2 \\
12,5 \% \\
\end{array}$ & $\begin{array}{c}16 \\
25,4 \% \\
\end{array}$ \\
\hline 7 & Discussion by topic & $\begin{array}{c}11 \\
57,9 \% \\
\end{array}$ & 0 & 0 & $\begin{array}{c}1 \\
20 \% \\
\end{array}$ & $\begin{array}{c}2 \\
20 \% \\
\end{array}$ & $\begin{array}{c}5 \\
31,2 \% \\
\end{array}$ & $\begin{array}{c}19 \\
30,2 \% \\
\end{array}$ \\
\hline 8 & Roleplay to solve the situation & $\begin{array}{c}2 \\
10,5 \% \\
\end{array}$ & $\begin{array}{c}1 \\
14,35 \\
\end{array}$ & $\begin{array}{c}1 \\
16,7 \% \\
\end{array}$ & $\begin{array}{c}1 \\
20 \% \\
\end{array}$ & $\begin{array}{c}5 \\
50 \% \\
\end{array}$ & $\begin{array}{c}5 \\
31,2 \% \\
\end{array}$ & $\begin{array}{c}15 \\
23,8 \% \\
\end{array}$ \\
\hline 9 & Other methods & $\begin{array}{c}1 \\
5,3 \%\end{array}$ & 0 & $\begin{array}{c}1 \\
16,7 \% \\
\end{array}$ & $\begin{array}{c}1 \\
20 \%\end{array}$ & $\begin{array}{c}1 \\
10 \%\end{array}$ & $\begin{array}{c}3 \\
18,8 \% \\
\end{array}$ & $\begin{array}{c}7 \\
11,1 \% \\
\end{array}$ \\
\hline
\end{tabular}

Table 4. Methods of using special education to educate students in teaching ethics in teaching Ethics

\begin{tabular}{|c|c|c|c|c|c|c|}
\hline \multirow[b]{2}{*}{ No } & \multirow[b]{2}{*}{ Method } & \multirow[b]{2}{*}{ Not used } & \multicolumn{4}{|c|}{ Used according to the lesson progress } \\
\hline & & & $\begin{array}{c}\text { Make lessons } \\
\text { Positive }\end{array}$ & Teaching theory & Practice lesson & Summary of lesson \\
\hline 1 & Storytelling folklore & & 0 & $\begin{array}{c}68 \\
71,6 \%\end{array}$ & $\begin{array}{c}19 \\
20 \%\end{array}$ & $\begin{array}{c}8 \\
8,4 \%\end{array}$ \\
\hline 2 & Question - Answer & & $\begin{array}{c}6 \\
6,3 \% \\
\end{array}$ & $\begin{array}{c}56 \\
58,9 \% \\
\end{array}$ & $\begin{array}{c}29 \\
30,5 \% \\
\end{array}$ & $\begin{array}{c}4 \\
4,2 \% \\
\end{array}$ \\
\hline 3 & Case study & & $\begin{array}{c}12 \\
12,6 \%\end{array}$ & $\begin{array}{c}58 \\
61,1 \% \\
\end{array}$ & $\begin{array}{c}17 \\
17,9 \%\end{array}$ & $\begin{array}{c}8 \\
8,4 \% \\
\end{array}$ \\
\hline 4 & Telling stories & & $\begin{array}{c}9 \\
9,5 \% \\
\end{array}$ & $\begin{array}{c}52 \\
54,7 \% \\
\end{array}$ & $\begin{array}{c}20 \\
21,1 \% \\
\end{array}$ & $\begin{array}{c}14 \\
14,7 \% \\
\end{array}$ \\
\hline 5 & $\begin{array}{c}\text { Roleplay to solve the } \\
\text { situation }\end{array}$ & & $\begin{array}{c}5 \\
5,3 \%\end{array}$ & $\begin{array}{c}30 \\
31,6 \%\end{array}$ & $\begin{array}{c}50 \\
52,6 \%\end{array}$ & $\begin{array}{c}10 \\
10,5 \%\end{array}$ \\
\hline
\end{tabular}


General assessment of the results of the current situation survey shows that the exploitation and use of local knowledge in educating children's rights and responsibilities for elementary students of Tay and Nung ethnic minorities have been managed by officials. and elementary teachers are well aware. Most teachers appreciate the superiority of local knowledge in the education of children's rights and responsibilities, and are therefore interested in implementing teaching and organizing educational activities in schools. However, the content, form and method of educating children's rights and responsibilities through the use of local knowledge are not thoroughly used by teachers, so the quality of education is not high. The reality of the process of organizing rights and duties education activities using local knowledge in the Northern Uplands shows that there is still a gap in theory and practice that need to be managed by educators and teachers. Elementary school students in the area of interest clarified [11].

Using local knowledge in educating rights and responsibilities for Tay and Nung elementary school students has affirmed its clear advantages, but the question is how to promote the effectiveness of the integration process of education. Practical research shows that, in order to effectively implement the process of educating rights and responsibilities for Tay and Nung elementary school students, it should be organized systematically in a plan and meet the goals and tasks. education set out [5]. In order to organize the above education process, it is necessary to build a system of specific measures to guide educational activities in the region's elementary schools.

\section{Conclusions}

Based on the cognitive characteristics of Tay and Nung elementary school students, in order to educate the rights and obligations effectively, we need to link the contents of these laws with real life. Using local knowledge is the realization of legal documents defining the rights and obligations of education for students in daily life. The knowledge with educational significance, with humanity present in the customs, living habits; in folk songs and proverbs; folk tales; performing arts; in life experience; religion, spirituality; in village conventions, in festivals, games, etc. This combination of education not only brings meaning to the education of the rights and duties of the students, but also the mode of transmission, conservation and enrichment. Cultural identity of the Tay and Nung ethnic communities [8]. Based on current practices and educational programs in elementary schools, the use of local knowledge to educate children's rights and responsibilities for students is carried out in two main ways through teaching. study dominant subjects and organize educational activities outside of class time [3].

The research results obtained in this project are the initial results that allow to affirm the value of local cultural knowledge in educating children's rights and responsibilities for Tay and Nung students. Moreover, these results are also a milestone for innovating the method of education in elementary schools, not only in the education of children's rights and responsibilities, but also in the comprehensive education of students. However, in order to be able to design a complete education program and implement it on a large scale, it is necessary to have the participation, suggestions and sharing of educational scientists, administrators and teachers. It is necessary to carry out the task of educating the children's rights and responsibilities at the elementary schools in each locality.

\section{Work Assignment}

We are both working together to complete the paper.

\section{Acknowledgements}

We would like to thank those who helped us to fill the survey in order to complete this paper.

\section{Source of Funding}

We would like to express our warm thanks to Thai Nguyen University of Education for financial support.

\section{REFERENCES}

[1] Covell, K., Howe, R. B., \& McNeil, J. K. Implementing children's human rights education in schools. Improving Schools, Vol. 13, No 2, 117-132, 2010.

[2] Will, M. C. Educating children with learning problems: A shared responsibility. Exceptional children, Vol.52, No.5, 411-415, 1986.

[3] Temperman, J. State neutrality in public school education: An analysis of the interplay between the neutrality principle, the right to adequate education, children's right to freedom of religion or belief, parental liberties, and the position of teachers. Hum. Rts. Q., Vol.32, 865, 2010.

[4] Alexander, R. Children, their world, their education. Final report and recommendations of the Cambridge Primary Review, 2010.

[5] Howe, R. B., \& Covell, K. Miseducating children about their rights. Education, Citizenship and Social Justice, Vol.5, No.2, 91-102, 2010.

[6] Hakuta, K. Educating language minority students and affirming their equal rights: Research and practical perspectives. Educational Researcher, Vol.40, No.4, 163-174, 2011.

[7] National Research Council. Educating one and all: Students 
with disabilities and standards-based reform. National Academies Press, 1997.

[8] Beckman, P., Abera, N., Sabella, T., Podzimek, K., \& Joseph, L. (2016). From rights to realities: Confronting the challenge of educating persons with disabilities in developing countries. Global Education Review, Vol.3, No.3.

[9] Doan, D. H. Moral education or political education in the Vietnamese educational system?. Journal of Moral
Education, Vol.34, No.4, 451-463, 2005.

[10] DeJaeghere, J., Wu, X., \& Vu, L. Ethnicity and education in China and Vietnam: discursive formations of inequality. Compare: A Journal of Comparative and International Education, Vol.45, No.1, 118-140, 2015

[11] Banks, J. A. Diversity, group identity, and citizenship education in a global age. Journal of Education, Vol.194, No.3, 1-12, 2014. 